\title{
SHELL VARIABILITY IN VESTIA TURGIDA (ROSSMÄSSLER, 1836) (GASTROPODA, CLAUSILIIDAE) ALONG AN ALTITUDINAL GRADIENT
}

\author{
ANNA SULIKOWSKA-DROZD
}

\begin{abstract}
Chair of Invertebrate Zoology and Hydrobiology, University of Łódź, Banacha 12/16, 90-237 Łódź, Poland (e-mail: sulik@biol.uni.lodz.pl)

ABSTRACT: 281 shells of Vestia turgida (Rossm.) were collected between 380 and 1,250 m a.s.l. in the Carpathians (Poland). Biometrical analysis revealed a correlation between metric characters of the shell, indices of shell shape and altitude. Snails living above the timberline had conspicuously smaller and stouter shells with weaker apertural barriers. The aperture shape did not differ along the altitudinal gradient. The stronger erosion of the shell surface at higher elevations depends probably on a longer juvenile period.
\end{abstract}

KEY WORDS: terrestrial snails, Clausiliidae, shell variability, morphometry, altitudinal gradient

\section{INTRODUCTION}

Land snails are well-known for their intraspecific variability. Local populations differ in terms of size, shell surface sculpture and coloration. This variability results from genetic differences and/or is environmentally induced. Size differences among populations have a high heritability (50-70\%) (GOODFRIEND 1986). A number of studies have also shown a significant ecological component to the shell form variation. Diverse environmental influences are usually difficult to assess, however there are a few common statements, e.g. that snails living in humid and shaded places have usually bigger shells.

Differences were also observed between populations from different altitudes. Many species at high altitudes produce surprisingly small shells in comparison to conspecific lowland populations (GOODFRIEND 1986). This could be caused by lower temperature, shorter vegetation season and heavier rainfall related to increasing elevation. It is stressed that general rules concerning variation among populations do not apply to high altitudes, more humid but at the same time colder and more insolated.

Some clausiliids exhibit a wide range of altitudinal distribution and reach up to 2,400 $\mathrm{m}$ a.s.l. in the Alps (KERNEY et al. 1983). Clausiliids are also known for their great variability of metric characters, rib formation and apertural barriers (LIKHAREV 1962). The variability of mountain species was commonly thought to be related to the sampling site elevation. LIKHAREV (1962) mentioned a less prominent formation of clausiliar apparatus in specimens from the mountains. BAIDASHNIKOV (1985) found a correlation between the shell height/width ratio and the altitude $(100-1,300 \mathrm{~m})$ for three species: Macrogastra latestriata (Schmidt), Pseudalinda stabilis (Pfeiffer) and Vestia gulo (Bielz) in the Eastern Carpathians. Unfortunately, the sample size in that study is unknown. According to BAIDASHNIKOV (1985) the shell size decrease with altitudinal gradient is caused by shorter vegetation season, limiting the time available for shell growth (temperature above $5^{\circ} \mathrm{C}$ ). In the Carpathians vegetation season lasts 234-275 days at the foothills and only 120-130 days in the subalpine zone.

A detailed analysis of the variability of $M$. latestriata in Poland (STEPCZAK 1970) revealed a strong relationship between the shell shape and temperature, while humidity differences were of minor importance. In STEPCZAK's (1970) opinion, the number of ribs is negatively correlated with the duration 


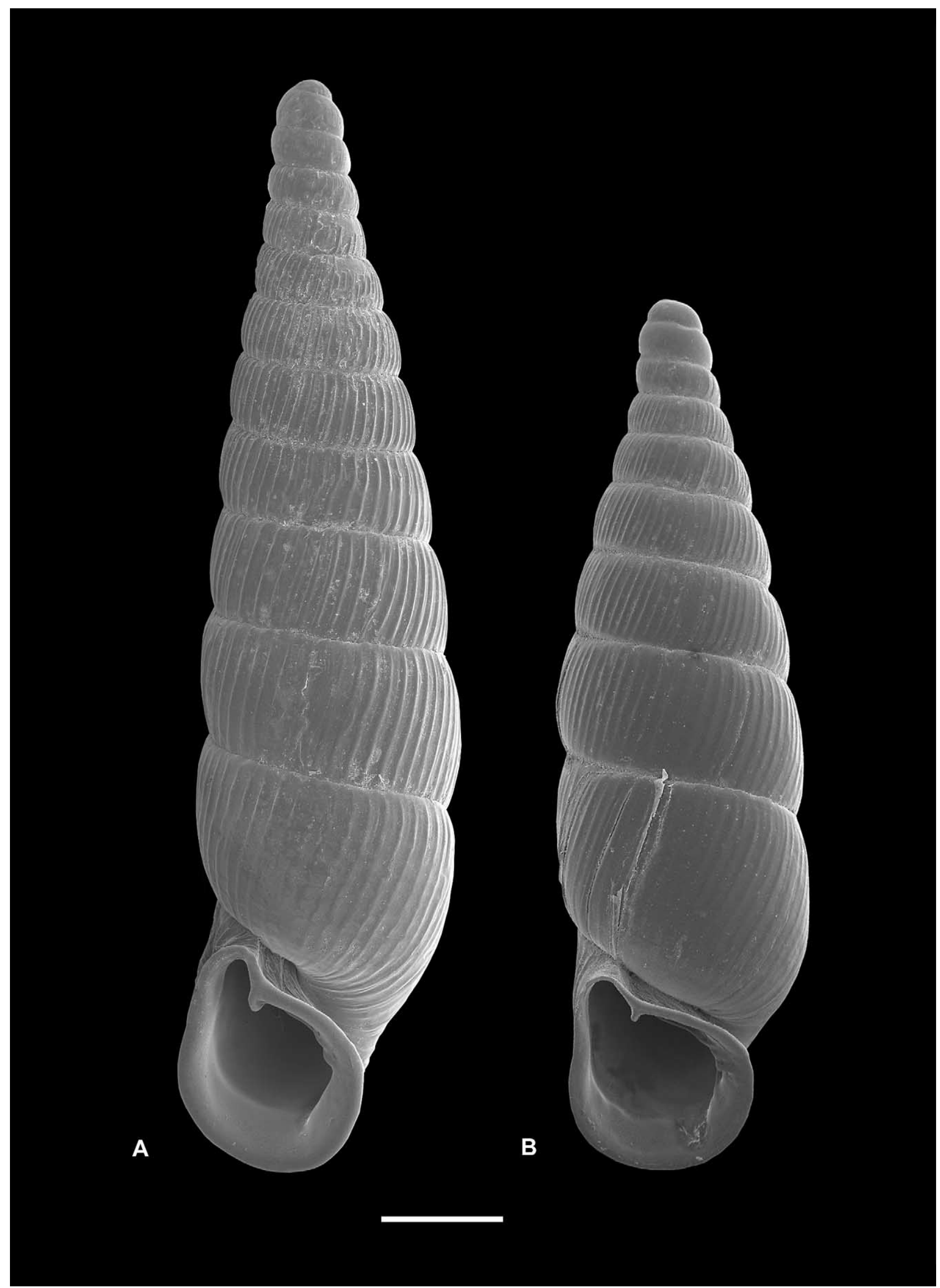

Fig. 1. Extreme forms of Vestia turgida: A - Tworylne, B - Wielka Rawka; scale bar - 2mm 
of vegetation season and reflects repeated changes in the snail's activity. The clausiliiar apparatus in M. latestriata was better developed in snails from warm regions (Pieniny Mts., Pogórze Przemyskie).

Shells of Alinda biplicata (Montagu) collected above $800 \mathrm{~m}$ a.s.l. in a wind-damaged forest were dwarfish and had poorly developed apertural barriers (WIKTOR 1964). The author supposed that the changes in morphology resulted from microclimatic fluctuations, strong winds and intense solar radiation.

Morphological variability of Clausilia dubia Draparnaud was studied in detail at various altitudes in the Alps. KLEMM (1960) tried to explain the observed distribution of subspecies by a complicated evolutionary scenario involving re-immigration after the Pleistocene and adaptation to harsh environment (altitude). He described populations with typical variation along the altitudinal gradient, and others, without any significant correlation between shell morphology and elevation. He believed that some subspecies might have evolved on Pleistocene nunataks while others invaded the Alps during post-glacial dispersal. Recent contacts between the mentioned populations would result in the wide variety of forms of Clausilia dubia. KLEMM's (1960) hypothesis about the predominant influence

\section{MATERIAL AND METHODS}

The material included a total of 281 shells collected between 380 and 1,250 m a. s. 1. in the Bieszczady Mts. and Beskid Niski Mts. (Table 1): $22 \%$ of the specimens were collected in the submontane zone, $50 \%$ in the mountain forest zone, and $28 \%$ above the timberline, i.e. at 1,000-1,260 $\mathrm{m}$ a.s.l. in the alpine region (ZARZYCKI \& GŁOWACIŃSKI 1986).

The following shell characters were analysed: eight metric characters (Fig. 2), four shape indices, number of whorls (accuracy $1 / 4$ whorl), number of ribs on the penultimate whorl, number of interlamellar folds in the aperture (between parietal lamella and lamella interior) and the surface erosion degree (Table 2). Measurements of shell height, width and aperture width were taken with $0.1 \mathrm{~mm}$ accuracy, others with $0.05 \mathrm{~mm}$ accuracy.

Intrapopulation variation of characters/indices and correlation (Pearson correlation coefficient $(r)$ ) between them were calculated. Correlation between shell characters and altitude was performed for all the collected specimens and separately for samples from below and above the timberline. Mean values of shell height and width were analysed with respect to the significance of differences (Student t-test) between populations collected above the timberline (78 specimens) and samples from the forest (26 specimens) within the same altitude range (1,000-1,250 $\mathrm{m}$ a.s.1.). of altitude on shell morphology was criticized by EDLINGER (1997), who performed biometrical analysis of C. dubia collected between 270 and $1,850 \mathrm{~m}$ in the same part of the Alps. He found that the correlation coefficient between altitude and shell height was low and statistically insignificant. The same was true of other shell characters. EDLINGER (1997) demonstrated that the idea of correlation between shell morphology and altitude was not well supported. BANK \& GITTENBERGER (2000) studied the variability of $C$. dubia along an altitudinal gradient, accounting the population distribution versus ice cover advances in the Italian Alps during the Pleistocene. Their results, though only preliminary, were in agreement with KLEMM's (1960) hypothesis.

Also Vestia turgida (Rossmässler, 1836) (Fig. 1) is known to build tumid, small shells in the high mountain zone (LOŽEK 1956, LIKHAREV 1962). The species is common in the northern part of the Carpathians (RIEDEL 1988), on the hills and on the highest ridges, above 2,000 $\mathrm{m}$ a.s.l. (DYDUCH-FALNIOWSKA 1991). As the species is highly variable, there is a need of detailed conchological study (DYDUCH-FALNIOWSKA 1991).

This paper presents the shell variability of Vestia turgida and its relation to altitude.
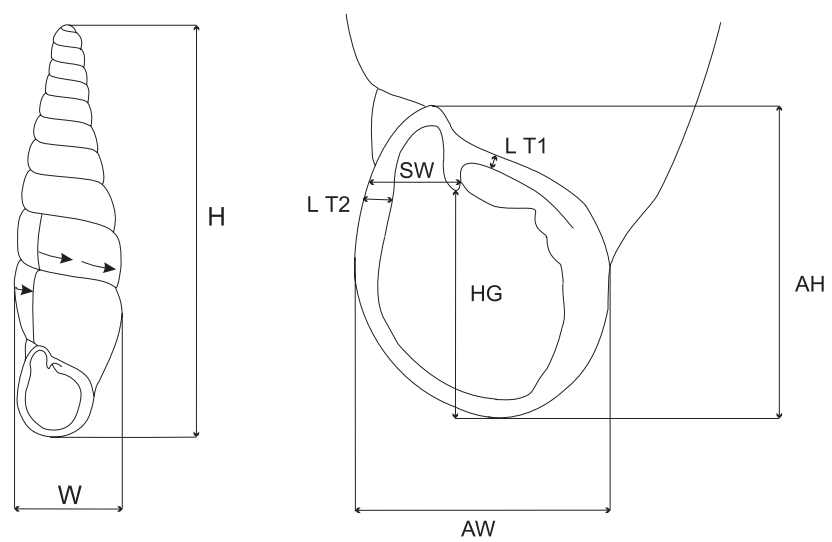

Fig. 2. Shell measurements of Vestia turgida. For variable designations see Table 2. Arrows on shell surface show the way of rib counting

Additionally, mean values of all characters/indices were compared for the three most abundant populations: Daliowa, Wołosate and Bukowe Berdo. When possible, variance analysis was applied (normalcy of distribution, homogeneity in variances), followed by post hoc tests (Tukey and Duncan tests). For other characters non-parametric Kruskal-Wallis test was adopted. Statistical analysis was performed with Statistica, version PL 5.1. 
Table 1. Examined samples

\begin{tabular}{|c|c|c|c|c|}
\hline & Collection site & $\begin{array}{l}\text { Altitude above sea level } \\
\qquad(\mathrm{m})\end{array}$ & $\begin{array}{l}\text { Number of specimens } \\
\qquad \Sigma=281\end{array}$ & $\begin{array}{l}\text { Habitat: } \mathrm{L} \text { - forest zone } \\
\mathrm{P} \text { - above timberline }\end{array}$ \\
\hline 1. & Ropica Górna & 380 & 16 & $\mathrm{~L}$ \\
\hline 2. & Daliowa & 425 & 37 & $\mathrm{~L}$ \\
\hline 3. & Tworylne & 475 & 8 & $\mathrm{~L}$ \\
\hline 4. & Dwernik & 525 & 19 & $\mathrm{~L}$ \\
\hline 5. & Pszczeliny & 550 & 16 & $\mathrm{~L}$ \\
\hline 6. & Bereżki & 650 & 5 & $\mathrm{~L}$ \\
\hline 7. & Rzeczyca & 665 & 8 & $\mathrm{~L}$ \\
\hline 8. & Wołosate/lower & 725 & 13 & $\mathrm{~L}$ \\
\hline 9. & Beniowa & 750 & 20 & $\mathrm{~L}$ \\
\hline 10. & Wołosate & 825 & 35 & $\mathrm{~L}$ \\
\hline 11. & Bukowe Berdo/lower & 1000 & 9 & $P$ \\
\hline 12. & Przełęcz Bukowska & 1050 & 5 & $\mathrm{~L}$ \\
\hline 13. & Okraglik & 1100 & 1 & $\mathrm{P}$ \\
\hline 14. & Czoło & 1120 & 18 & $\mathrm{~L}$ \\
\hline 15. & Bukowe Berdo & 1150 & 34 & $\mathrm{P}$ \\
\hline 16. & Bukowe Berdo/upper & 1180 & 6 & $\mathrm{P}$ \\
\hline 17. & Połonina Caryńska & 1200 & 5 & $\mathrm{P}$ \\
\hline 18. & Rozsypaniec & 1200 & 4 & $\mathrm{P}$ \\
\hline 19. & Krzemień & 1150 & 3 & $\mathrm{P}$ \\
\hline 20. & Krzemień & 1200 & 6 & $\mathrm{P}$ \\
\hline 21. & Krzemień & 1250 & 1 & $P$ \\
\hline 22. & Wielka Rawka/forest & 1250 & 3 & $\mathrm{~L}$ \\
\hline 23. & Wielka Rawka & 1250 & 9 & $\mathrm{P}$ \\
\hline
\end{tabular}

Table 2. Variables

\begin{tabular}{ll}
\hline Abbreviation & Characters/indices \\
\hline H & shell height \\
W & shell width \\
AH & aperture height \\
HG & distance between parietal lamella and the lower edge of the aperture \\
AW & aperture width \\
SW & sinulus width \\
LT1 & lip thickness near parietal lamella \\
LT2 & lip thickness below the sinulus \\
H/W & height/width ratio \\
AH/AW & aperture height/width ratio \\
(H-AH)/H & spire height/shell height ratio \\
W/AW & shell width/aperture width ratio \\
NW & number of whorls \\
H/NW & shell height/number of whorls ratio \\
NF & number of interlamellar folds \\
NR & number of ribs on penultimate whorl \\
ER [\%] & surface erosion degree \\
\hline
\end{tabular}




\section{RESULTS}

Table 3 presents descriptive statistics of the examined characters/indices. Variability coefficients for most of the characters do not exceed $10 \%$. They reach higher values for the lip thickness, the number of ribs, the number of interlamellar folds in the aperture and the surface erosion degree.

Most of the examined characters/indices were correlated (Bonferroni correction $\mathrm{p}<0.000001$ was applied) (Table 4). The highest positive correlations were those between the following characters: number of whorls and height/width ratio: 0.88 ; number of whorls and shell height: 0.85 ; number of whorls and spire/shell height ratio: 0.74; aperture width and sinulus width: 0.73; aperture height and width: 0.72; shell height and aperture height: 0.71 ; shell height and aperture width: 0.70 . Negative correlations were found between: height/width ratio and shell width/aperture width ratio: -0.55 ; height/width ratio and number of ribs: -0.52 ; number of whorls and number of ribs: -0.48 ; shell height and number of ribs: -0.48 .

Shells with more numerous whorls are higher and more slender (height/width ratio). Moreover, they have relatively higher spires, larger aperture with thicker lip and fewer ribs on the penultimate whorl. The aperture height/width ratio, the number of interlamellar folds and the surface erosion degree do not correlate with any other variables.

Correlation between the examined characters/indices and the elevation of the collection site is statisti- cally significant (Table 5: column I, Fig. 3). Snails inhabiting higher altitudes build smaller and stouter shells, with fewer whorls, shorter spire and slightly smaller aperture. The lip below the sinulus is thinner, and there are fewer interlamellar folds in the aperture. The number of ribs (Fig. 4) and the degree of surface erosion significantly increase. Additionally, the difference between shell width and aperture width increases. Conversely, the shell width, sinulus width and the shape of aperture do not exhibit any correlation with altitude.

Correlation coefficients calculated separately for the forest zone and the higher mountain zone above the timberline differ from each other (Table 5: columns II, III). In the forest zone, correlation between characters and elevation is weaker than that calculated for all specimens. For the higher mountain zone samples no correlation exists.

Mean values of the shell height and width from above the timberline are significantly smaller $(p<0.01)$ then those from the forest at the same altitude (Figs 5, 6).

Variance analysis revealed significant differences between mean shell height $(\mathrm{H})$, aperture height $(\mathrm{AH})$, spire height/shell height $((\mathrm{H}-\mathrm{AH}) / \mathrm{H})$ and shell height/width $(\mathrm{H} / \mathrm{W})$ ratios for the three examined populations (Table 6, Fig. 7). The hypothesis that means are equal cannot be rejected only for aperture height/width (AH/AW) ratio (Fig. 8). Post hoc tests show that each population is different from the

Table 3. Descriptive statistics of the examined shell characters/indices of Vestia turgida shell

\begin{tabular}{|c|c|c|c|c|c|c|}
\hline Variable* & Mean & Median & Minimum & Maximum & SD & Variability coefficient \\
\hline $\mathrm{H}$ & 14.34 & 14.25 & 11.25 & 18.75 & 1.29 & 0.09 \\
\hline W & 4.13 & 4.12 & 3.60 & 4.73 & 0.19 & 0.05 \\
\hline $\mathrm{AH}$ & 3.32 & 3.31 & 2.63 & 3.87 & 0.21 & 0.06 \\
\hline $\mathrm{HG}$ & 2.49 & 2.50 & 2.06 & 3.00 & 0.15 & 0.06 \\
\hline AW & 2.79 & 2.80 & 2.30 & 3.25 & 0.17 & 0.06 \\
\hline SW & 0.97 & 0.97 & 0.75 & 1.16 & 0.07 & 0.07 \\
\hline LT1 & 0.28 & 0.27 & - & 0.57 & 0.07 & 0.25 \\
\hline LT2 & 0.31 & 0.30 & 0.08 & 0.49 & 0.07 & 0.23 \\
\hline $\mathrm{H} / \mathrm{W}$ & 3.47 & 3.44 & 2.93 & 4.24 & 0.27 & 0.08 \\
\hline $\mathrm{AH} / \mathrm{AW}$ & 1.19 & 1.19 & 1.06 & 1.40 & 0.06 & 0.05 \\
\hline$(\mathrm{H}-\mathrm{AH}) / \mathrm{H}$ & 0.77 & 0.77 & 0.73 & 0.81 & 0.02 & 0.03 \\
\hline $\mathrm{W} / \mathrm{AW}$ & 1.49 & 1.50 & 1.32 & 1.72 & 0.07 & 0.05 \\
\hline NW & 9.95 & 9.75 & 8.50 & 12.00 & 0.72 & 0.07 \\
\hline $\mathrm{H} / \mathrm{AW}$ & 1.44 & 1.44 & 1.25 & 1.65 & 0.09 & 0.06 \\
\hline $\mathrm{NF}$ & 0.3 & 0 & 0 & 2 & 0.54 & 1.80 \\
\hline NR & 50.7 & 50 & 38 & 70 & 6 & 0.12 \\
\hline ER & 7 & 5 & 0 & 60 & 9 & 1.29 \\
\hline
\end{tabular}

*For variable designation see Table 2. 
Table 4. Coefficients of correlation between shell characters/indices

\begin{tabular}{|c|c|c|c|c|c|c|c|c|c|c|c|c|c|c|c|c|}
\hline & NW & $\mathrm{H}$ & $\mathrm{AH}$ & HG & $\mathrm{W}$ & $\mathrm{AW}$ & SW & LT1 & LT2 & NR & $\mathrm{NF}$ & ER & $\mathrm{H} / \mathrm{W}$ & $\mathrm{AH} / \mathrm{AW}$ & W/AW & $\mathrm{H} / \mathrm{NW}$ \\
\hline \multicolumn{17}{|l|}{ NW } \\
\hline $\mathrm{H}$ & $0.85^{*}$ & & & & & & & & & & & & & & & \\
\hline $\mathrm{AH}$ & $0.45^{*}$ & $0.71^{*}$ & & & & & & & & & & & & & & \\
\hline $\mathrm{HG}$ & $0.40^{*}$ & $0.70^{*}$ & $0.89^{*}$ & & & & & & & & & & & & & \\
\hline $\mathrm{W}$ & 0.22 & $0.53^{*}$ & $0.65^{*}$ & $0.71^{*}$ & & & & & & & & & & & & \\
\hline AW & $0.47^{*}$ & $0.70^{*}$ & $0.72^{*}$ & $0.68^{*}$ & $0.64^{*}$ & & & & & & & & & & & \\
\hline SW & $0.36^{*}$ & $0.53^{*}$ & $0.58^{*}$ & $0.50^{*}$ & $0.50^{*}$ & $0.73^{*}$ & & & & & & & & & & \\
\hline LT1 & 0.21 & 0.24 & $0.33^{*}$ & 0.26 & 0.17 & $0.33^{*}$ & $0.29^{*}$ & & & & & & & & & \\
\hline LT2 & $0.33^{*}$ & $0.40^{*}$ & $0.34^{*}$ & 0.25 & 0.22 & $0.50^{*}$ & $0.51^{*}$ & $0.43^{*}$ & & & & & & & & \\
\hline NR & $-0.48^{*}$ & $-0.48^{*}$ & $-0.29^{*}$ & -0.21 & -0.09 & $-0.30^{*}$ & -0.22 & -0.26 & $-0.37^{*}$ & & & & & & & \\
\hline NF & 0.22 & 0.15 & 0.09 & 0.05 & -0.06 & 0.14 & 0.08 & -0.02 & 0.07 & -0.22 & & & & & & \\
\hline ER & -0.19 & -0.08 & 0.00 & 0.01 & 0.14 & -0.12 & -0.17 & 0.08 & 0.05 & 0.07 & -0.17 & & & & & \\
\hline $\mathrm{H} / \mathrm{W}$ & $0.88^{*}$ & $0.86^{*}$ & $0.45^{*}$ & $0.37^{*}$ & 0.03 & $0.45^{*}$ & $0.34^{*}$ & 0.19 & $0.34^{*}$ & $-0.52^{*}$ & 0.22 & -0.18 & & & & \\
\hline $\mathrm{AH} / \mathrm{AW}$ & 0.02 & -0.01 & 0.05 & 0.00 & -0.07 & -0.02 & 0.04 & 0.03 & -0.02 & -0.05 & -0.04 & 0.03 & 0.04 & & & \\
\hline $\mathrm{W} / \mathrm{AW}$ & $-0.40^{*}$ & $-0.41^{*}$ & $-0.33^{*}$ & -0.22 & 0.11 & $-0.69^{*}$ & $-0.48^{*}$ & -0.26 & $-0.45^{*}$ & $0.30^{*}$ & -0.23 & $0.30^{*}$ & $-0.55^{*}$ & -0.04 & & \\
\hline $\mathrm{H} / \mathrm{NW}$ & 0.07 & $0.44^{*}$ & $0.46^{*}$ & $0.50^{*}$ & $0.54^{*}$ & $0.46^{*}$ & $0.38^{*}$ & 0.17 & 0.21 & -0.12 & -0.16 & 0.14 & 0.20 & -0.04 & -0.09 & \\
\hline$(\mathrm{H}-\mathrm{AH}) / \mathrm{H}$ & $0.74^{*}$ & $0.68^{*}$ & -0.03 & 0.03 & 0.08 & 0.26 & 0.16 & 0.01 & 0.22 & $-0.40^{*}$ & 0.12 & -0.10 & $0.75^{*}$ & -0.06 & -0.25 & 0.16 \\
\hline
\end{tabular}

*significant $\mathrm{p}<0.000001$ (no asterisk - not significant)

For variable designations see Table 2.

Table 5. Pearson correlation coefficients (r) between shell characters/indices and altitude

\begin{tabular}{|c|c|c|c|}
\hline \multirow{2}{*}{ Variable } & I & II & III \\
\hline & Total $\mathrm{n}=281$ & Forest zone $\mathrm{n}=203$ & Above timberline $\mathrm{n}=78$ \\
\hline NW & $-0.68^{* *}$ & $-0.54^{* *}$ & -0.04 n.s. \\
\hline $\mathrm{H}$ & $-0.56^{* *}$ & $-0.27^{* *}$ & -0.17 n.s. \\
\hline $\mathrm{AH}$ & $-0.23^{* *}$ & 0.07 n.s. & 0.01 n.s. \\
\hline HG & $-0.18^{* *}$ & 0.14 n.s. & 0.00 n.s. \\
\hline $\mathrm{W}$ & 0.00 n.s. & $0.27^{* *}$ & 0.00 n.s. \\
\hline AW & $-0.30^{* *}$ & 0.09 n.s. & -0.18 n.s. \\
\hline SW & $-0.21^{* *}$ & 0.06 n.s. & -0.06 n.s. \\
\hline LT1 & -0.09 n.s. & 0.10 n.s. & -0.11 n.s. \\
\hline LT2 & $-0.36^{* *}$ & $-0.15^{*}$ & -0.22 n.s. \\
\hline NR & $0.50^{* *}$ & $0.32^{* *}$ & 0.03 n.s. \\
\hline $\mathrm{NF}$ & $-0.28^{* *}$ & $-0.13^{*}$ & -0.07 n.s. \\
\hline ER & $0.23^{* *}$ & $0.40^{* *}$ & -0.08 n.s. \\
\hline $\mathrm{H} / \mathrm{W}$ & $-0.65^{* * *}$ & $-0.49^{* *}$ & -0.18 n.s. \\
\hline $\mathrm{AH} / \mathrm{AW}$ & -0.08 n.s. & -0.07 n.s. & $0.23^{*}$ \\
\hline $\mathrm{W} / \mathrm{AW}$ & $0.39^{* *}$ & $0.17^{*}$ & 0.21 n.s. \\
\hline $\mathrm{H} / \mathrm{NW}$ & 0.01 n.s. & $0.24^{* *}$ & -0.17 n.s. \\
\hline$(\mathrm{H}-\mathrm{AH}) / \mathrm{H}$ & $-0.56^{* *}$ & $-0.43^{* *}$ & -0.21 n.s. \\
\hline
\end{tabular}

*significant $\mathrm{p}<0.05$

** significant $\mathrm{p}<0.01$

n.s. not significant

For variable designations see Table 2.

remaining two in terms of $\mathrm{H}, \mathrm{AH},(\mathrm{H}-\mathrm{AH}) / \mathrm{H}$ and $\mathrm{H} / \mathrm{W}$ variables. All variables except $\mathrm{HG}$, compared with non-parametric Kruskal-Wallis test, are significantly different among the three populations (Table
7, Figs 9, 10). The least variable shell characters of Vestia turgida are the shape of aperture and HG. None of them differs among the studied populations. 


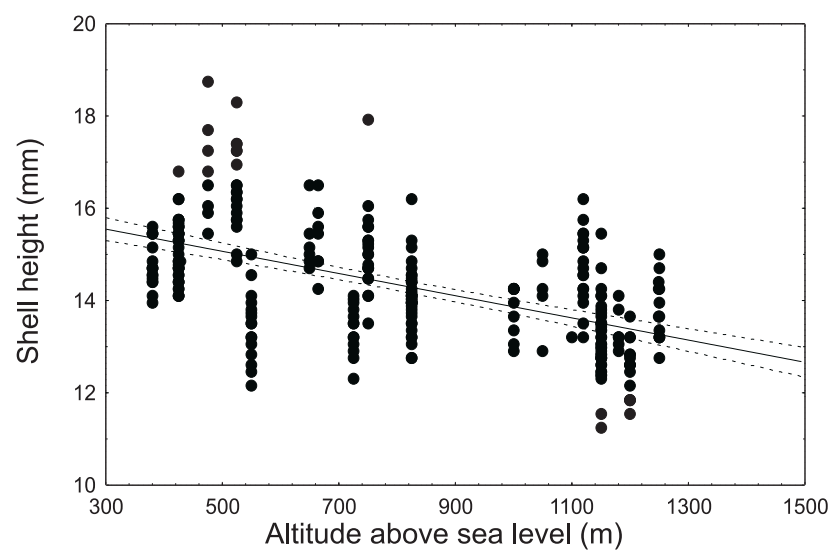

- Regression $95 \%$ confidence interval

Fig. 3. Vestia turgida. Shell height plotted against altitude. $\mathrm{H}=$ $16.27-0.0024$ a.s.1.; $r=-0.5554$

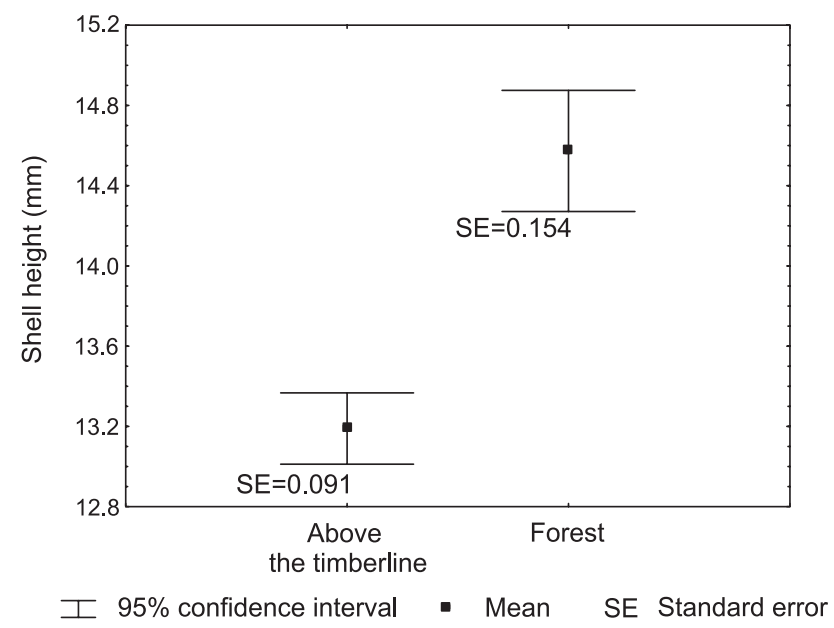

Fig. 5. Vestia turgida. Shell height at 1,000-1,250 m a.s.l. in different habitats

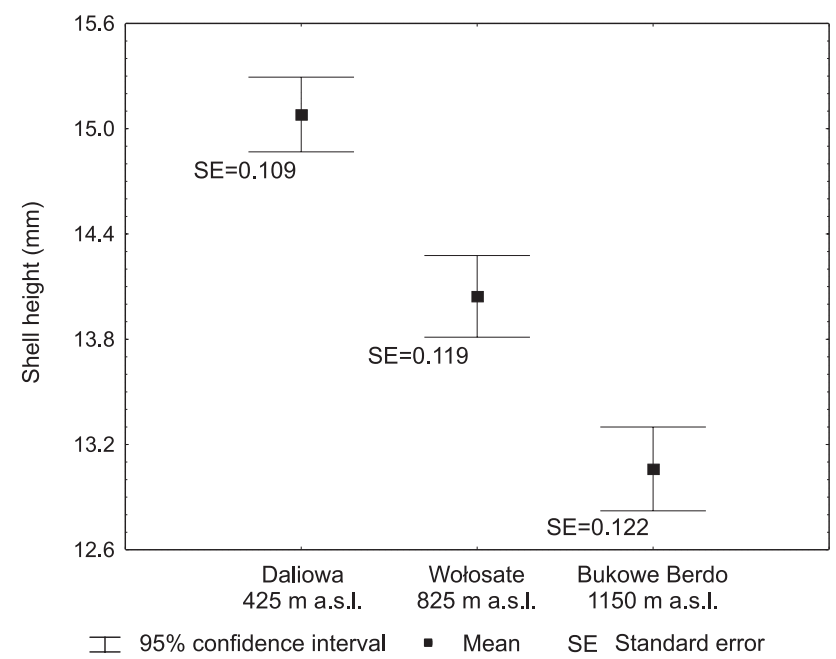

Fig. 7. Shell height in three populations of Vestia turgida

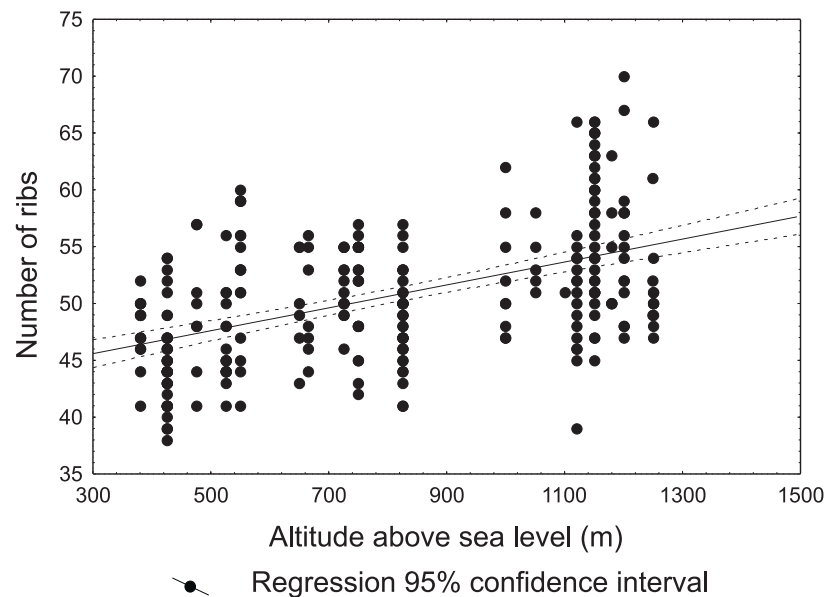

Fig. 4. Vestia turgida. Number of ribs on penultimate whorl plotted against altitude. $\mathrm{NR}=42.559+0.01008$ a.s.l.; $\mathrm{r}=$ 0.49674

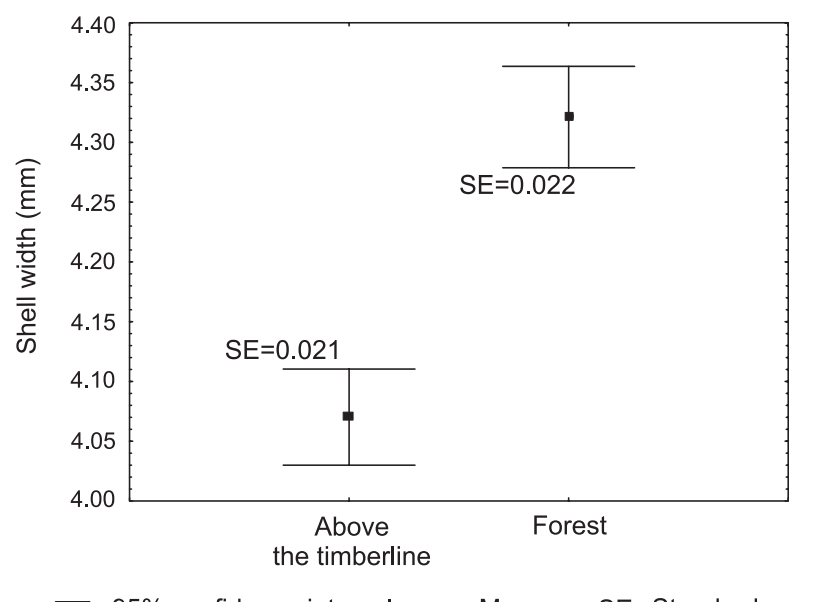

Fig. 6. Vestia turgida. Shell width at 1,000-1,250 $\mathrm{m}$ a.s.1. in different habitats

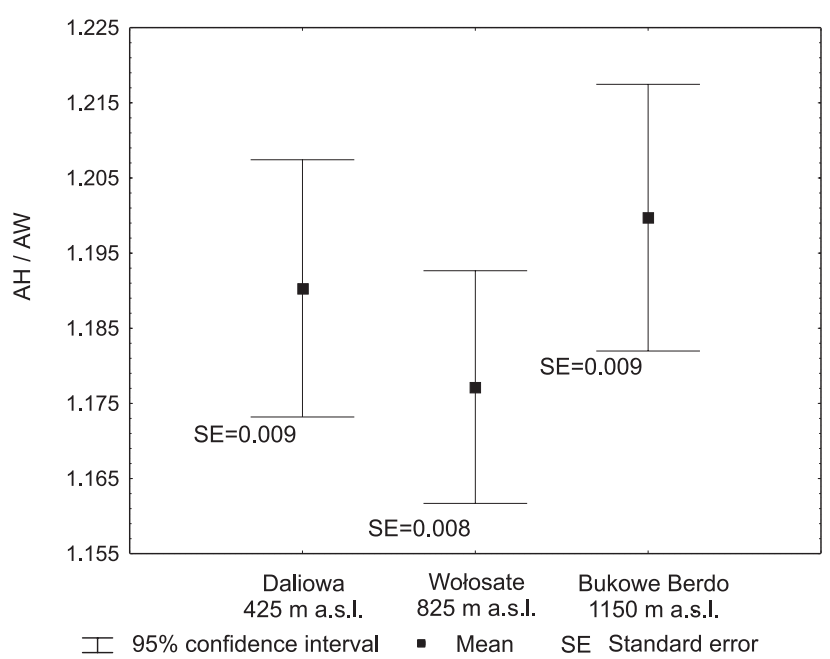

Fig. 8. Aperture height/width ratio in three populations of Vestia turgida 


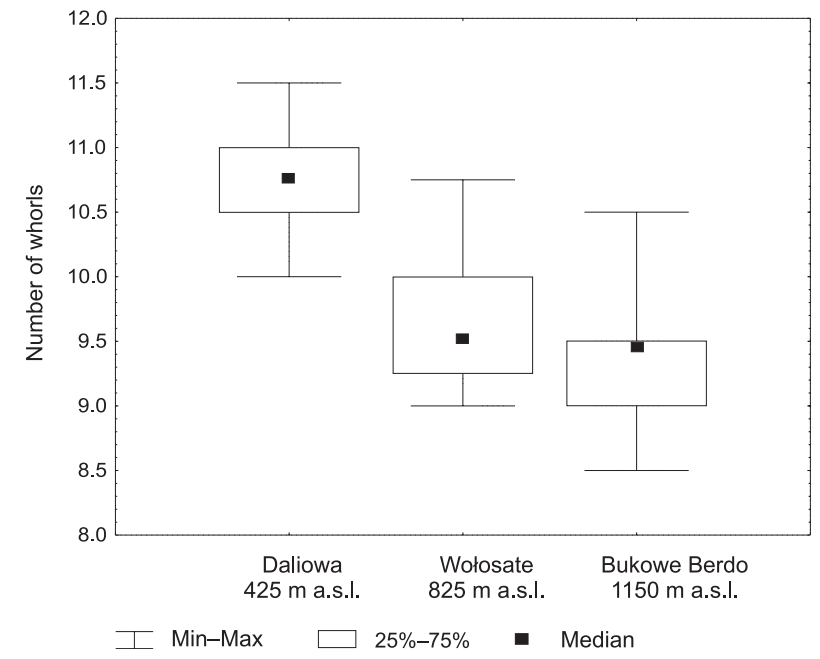

Fig. 9. Number of whorls in three populations of Vestia turgida

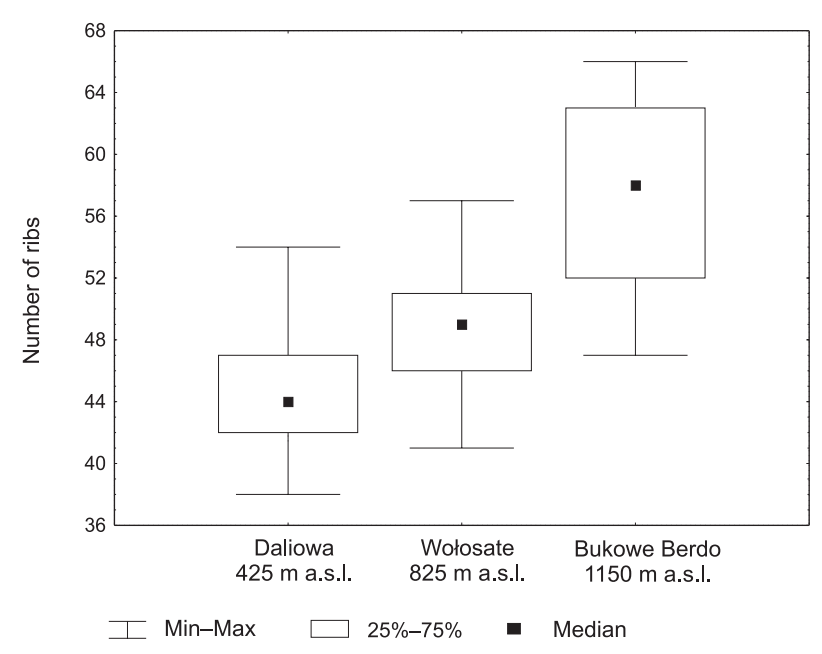

Fig. 10. Number of ribs on penultimate whorl in three populations of Vestia turgida

Table 6. Results of variance analysis for three populations of Vestia turgida

\begin{tabular}{lrcccrcc}
\hline \multirow{2}{*}{ Variables } & \multicolumn{2}{c}{ Daliowa } & \multicolumn{2}{c}{ Wołosate } & \multicolumn{2}{c}{ Bukowe Berdo } \\
\cline { 2 - 8 } & mean & SD & mean & SD & mean & SD & function F \\
\hline H & 15.081 & 0.661 & 14.044 & 0.702 & 13.061 & 0.711 & $75.43^{*}$ \\
AH & 3.375 & 0.133 & 3.288 & 0.114 & 3.207 & 0.161 & $13.411^{*}$ \\
H/W & 3.725 & 0.185 & 3.406 & 0.150 & 3.209 & 0.145 & $92.607^{*}$ \\
AH/AW & 1.190 & 0.053 & 1.177 & 0.047 & 1.200 & 0.053 & 1.705 n.s. \\
$(\mathrm{H}-\mathrm{AH}) / \mathrm{H}$ & 0.776 & 0.011 & 0.765 & 0.012 & 0.754 & 0.013 & $29.922^{*}$ \\
\hline
\end{tabular}

*significant $\mathrm{p}<0.001$

n.s. not significant

For variable designations see Table 2.

Table 7. Results of non-parametric Kruskal-Wallis test for three populations ( $\mathrm{df}=2)$ of Vestia turgida

\begin{tabular}{lcccc}
\hline \multirow{2}{*}{ Variables } & Daliowa $\mathrm{n}=37$ & Wołosate $\mathrm{n}=35$ & Bukowe Berdo $\mathrm{n}=34$ & \multirow{2}{*}{ Chi square } \\
\cline { 2 - 3 } NW & \multicolumn{3}{c}{ Sum of ranks } & $60.3395^{*}$ \\
HG & 3167.5 & 1531.0 & 972.5 & 0.4305 n.s. \\
W & 2190.0 & 1948.0 & 1533.0 & $8^{*}$ \\
AW & 1655.0 & 2257.0 & 1759.0 & $16.9396^{*}$ \\
SW & 2509.0 & 2071.0 & 1091.0 & $21.4518^{*}$ \\
LT1 & 2244.0 & 2215.5 & 1211.0 & $21.5500^{*}$ \\
LT2 & 2435.0 & 1990.5 & 1245.5 & $19.1583^{*}$ \\
NR & 2359.5 & 2216.0 & 1095.0 & $46.8665^{*}$ \\
NF & 1078.5 & 1712.5 & 2880.0 & $26.0514^{*}$ \\
ER & 2545.0 & 1766.5 & 1359.0 & $26.6404^{*}$ \\
W/AW & 1206.0 & 2706.5 & 1758.5 & $36.6712^{*}$ \\
H/NW & 1180.0 & 1918.5 & 2572.5 & $13.3768^{*}$ \\
\hline
\end{tabular}

*significant $\mathrm{p}<0.05$

n.s. not significant

For variable designations see Table 2. 


\section{DISCUSSION}

The examined shell parameters display a wider intrapopulation variability than that reported by LOŽEK (1956) (shell height 12-17.5 mm). The variability significantly correlated with altitude is probably caused by the influence of current climatic factors. Populations from the Beskid Niski Mts. and Bieszczady Mts. were never split by the ice cover. The recorded variation of $V$. turgida supports the relationship between shell formation and elevation, questioned by EDLINGER (1997). The shell variability of $V$. turgida features follows the pattern known for clausiliids (STEPCZAK 1970, BAIDASHNIKOV 1985). It should be mentioned that the aperture shape is the least polymorphic in all the examined populations. This suggests that the character does not depend on environmental factors.

Climate harshness related to altitude does not influence species uniformly along the gradient but discrete changes could be distinguished. The most important boundary is the timberline, above which the correlation between the shell form and altitude disappears. Specimens from above the timberline are significantly smaller than those living at the same altitude in the forest.

An opposite dependence was observed by BAUR \& RABOUD (1988), who noticed conspicuously large

\section{REFERENCES}

BAIDASHNIKOV A. A. 1985. Osobennosti vertikalnogo raspredeleniya nazemnoy malakofauny Zakarpat'ya. Vestnik zoologii, Kiev.

BANK R., GitTENBERGer E. 2000. On the polytypic and problematic Clausilia dubia: notes on its nomenclature and systematics (Gastropoda, Pulmonata, Clausiliidae). Basteria 64: 15-27.

BAUR B. 1984. Shell size and growth rate differences for alpine populations of Arianta arbustorum (L.) (Pulmonata: Helicidae). Revue Suisse Zool. 91: 37-46.

BAUR B., RABOUD CH. 1988. Life history of the land snail Arianta arbustorum along an altitudinal gradient. J. Animal Ecol. 57: 71-87.

Dyduch-FAlniowska A. 1991. The gastropods of the Polish Tatra Mountains. Zakład Ochrony Przyrody i Zasobów Naturalnych PAN, Kraków.

EDLINGER K. 1997. Morphological and biometrical researches on Austrian Clausiliids. Shell morphology and variability in Clausilia dubia Draparnaud, 1805. Iberus 15: 95-121.

GOODFRIEND G. A. 1986. Variation in land-snail shell form and size and its causes: a reviev. Syst. Zool. 35: 204-223.

KLemm W. 1960. Clausilia dubia Draparnaud und ihre Formen in Österreich. Arch. Moll. 89: 81-109. (for such an altitude) shells of Arianta arbustorum (L.) just above the timberline. The altitudinal range of the collection sites above the timberline in the Bieszczady Mts was small, thus no final conclusions can be drawn. Nevertheless the increasing insolation and temperature instability should be regarded as important factors influencing the shell formation in high mountain populations.

Surprisingly, the degree of surface erosion was also significantly correlated with altitude. The phenomenon could result from inter-population differences in life history, which in V. turgida has never been studied. It is likely that, like other snail species (UMIŃSKI 1975, BAUR 1984, BAUR \& RABOUD 1988), Vestia from high mountain populations matures after much longer development time than its conspecifics from lower locations. According to BAUR (1984), in the helicid Arianta arbustorum the time between hatching and maturity is even five times longer in the Alps as a result of a shorter vegetation season and a slower development rate of juveniles. Adults from high mountain populations are probably much older and therefore their shells are more eroded.

Kerney M. P., Cameron R. A. D., Junghbuth J. H. 1983. Die Landschnecken Nord- und Mitteleuropas. Verlag Paul Parey, Hamburg \& Berlin.

LIKHAREV I. M. 1962. Klauziliidy (Clausiliidae). Fauna SSSR. N. S. 83. Nauka, Moskwa-Leningrad.

LOŽEK V. 1956. Klič Československých mèkky̌šů. Bratislava.

RIEDEL A. 1988. Ślimaki lądowe. Gastropoda terrestria. Katalog Fauny Polski 46. PWN, Warszawa.

SOKAL R., RohlF F. J. 1995. Biometry. W. H. Freeman \& Co., New York.

STĘPCZAK K. 1970. Zmienność świdrzyka żeberkowanego Iphigena latestriata (A. Schmidt, 1857) (Clausiliidae, Gastropoda). PTPN, Wydz. Mat. Przyr. Pr. Kom. Biol. 33: $1-74$.

UMIŃSKI T. 1975. Reproductive maturity in some Vitrinidae (Mollusca, Gastropoda) from Poland. Ann. Zool. 32: 357.

WiKTOR A. 1964. Mięczaki Ziemi Kłodzkiej i gór przyległych. Studium faunistyczno-zoogeograficzne. PTPN, Wydz. Mat. Przyr. Pr. Kom. Biol. 19: 1-132.

ZARZYCKI K., GŁOWACiŃski Z. 1986. Bieszczady. Wiedza Powszechna, Warszawa.

received: August 15th, 2000

accepted: February 25th, 2001 